номия в рамките на придобитите компетенции, въпроси, които в редица европейски страни са разрешени. Ако се създадат възможности за кариерно развитие и професионална реализация с даване на възможност сестрите и акушерките при придобити компетенции да оказват грижи за приоритетни групи от населението - жените, децата, възрастните и старите хора, здравната ни система ще предложи по-добри грижи и ще отговори на обществените очаквания. Изграждането на Сестрински служби, Акушерски центрове и други иновативни за страната ни форми ще способстват ресурса, с който разполагаме - медицинските сестри и акушерките с висока квалификация, с придобито университетско образование, специализации и непрекъснато обучение, да се използват ефективно от здравната система.

\section{Автор}

Проф. д-р Соня Тончева, Медицински университет - Варна

\title{
ЗДРАВНИТЕ ГРИЖИ В СЕКТОРА „ПЪРВИЧНА ИЗВЪНБОЛНИЧНА МЕДИЦИНСКА ПОМОЩ" - ПОГЛЕД ПРЕЗ ПРИЗМАТА НА ЗДРАВНАТА РЕФОРМА
} П. Николаков

\section{HEALTHCARE IN THE SECTOR "PRIMARY OUTPATIENT HEALTH CARE" - VIEW THROUGH THE PRISM OF THE HEALTHCARE REFORM P. Nikolakov}

Резюме. В статията се обсъждат здравните грижи в сектора „първична извънболнична медицинска помощ“", които са в продължителен процес на реформиране. Стоят за решаване съществени въпроси, свързани с ниския статут и заплащането на медицинските сестри, подиеняването на здравната профилактика, неподходящите за здравеопазването пазарни механизми и пречещите идеологически противоборства.

S u $\mathbf{m} \boldsymbol{m}$ a r y. The paper treats health care practices in the sector "Primary Outpatient Health Care" which are continuously being reformed. Important issues are expecting to be managed, related to nurses'low statute and wages, underestimation of health prevention, market mechanisms, inadequate for health care and obstructing ideological contradictions.

3

дравните грижи в сектора „Първична извънболнична медицинска помощ“, въпреки неоспоримата им роля в интегритета на предния фронт на здравеопазването, имат доста колеблива връзка с продължителния процес на неговото реформиране. От една страна документите, постулиращи мястото и ролята им в 28-годишния реформаторски демарш [1, 2] обикновено изтькват тяхната значимост, а от друга повечето от реформаторските стъпки за разширяване на обхвата и подобряване на качеството им се блокират от широко афиширания недостиг на финансови средства за техните изпълнители. Поради това те както сега, така и в близко бъдеще ще се възприемат само като периферен елемент на първо ешалонния сектор в системата на здравеопазването.

Във връзка с тази неблагоприятна прогноза е необходимо с присъщата на съсловието цивилизационна настойчивост отново да поставим на вниманието на политици, държавни дейци, съсловни организации в здравеопазването, ръководства на бъдещи демонополизирани здравно осигурителни каси и здравнозастрахователни дружества (фондове) и не на последно место на организациите за защита правата на пациентите въпроса за тяхната реабилитация и за освобождаването им от организационния ,, арест”, в който се намират.

Контекстуално, само по себе си, това означава отново да подчертаем интеграционната роля на изпълнителите от системата за първична извънболнична медицинска помощ и в частност ролята на професионалистите по здравни грижи.

Тук преди всичко е необходимо да си припомним четирите стратегически елемента на първичната медицинска помощ, прокламирани в декларацията от Алма-Ата:

- необходимост от преориентация на здравните услуги по начин, който поставя първичната медицинска помощ в основата на системата за здравеопазване и отрежда спомагателни функции на специализираната извънболнична и болнична помощ, до която се прибягва само когато за тях е издадено направление;

- концепция за здравна политика, която включва фактори, въздействащи върху здравето, каквито са начинът на живот и околната среда, т.е. разбирането за необходимост за междуотраслов подход към здравната политика;

- обществена и лична ангажираност, свързана с участие в процеса на вземане на решения, както и с по-голяма лична отговорност за здравето;

- подходящи технологии и разходна ефективност, които включват ефективното разпределение на ресурсите в здравеопазването, на тяхното преразпределение в полза на първичната медицинска помощ и на целия, съдържащ се в нея пакет „здравни грижи” за сметка на болничната помощ.

Не е тайна, че в годините на прехода се напластиха редица негатитивни факти в общественото здравеопазване, изразяващи се в:

> верижен емоционален срив в потребителите и изпълнителите на първична извънболнична медицинска помощ, породен от несъответствието между отлично формулираните във всяка поредна национална здравна стратегия политически намерения за смислена реформа в този сектор на здравеопазването и резултатите от тях.

> подценяване на значимостта на здравната профилактика като генерално направление на всяка цивилизована национална здравна система;

- вълнуваща идеологическа схватка между привържениците за обществено регулирана национална здравна карта в лечебната сфера на здравеопазването и привържениците на напълно свободното пазарно предприемачество в нея, която по острота и драматизъм се нарежда до библейската схватка между Исус и фарисеите в храма на Сaваот; 
- лишаване на населението в стотици селски населени места от първична извънболнична медицинска помощ и здравни грижи;

- обезличаване на фамилната (семейната) ориентация в организацията на първичната извънболнична медицинска помощ и здравни грижи.

Въпреки това в отделни населени места и групови фамилни практики бе направен сполучлив опит за по-широко възприемане на принципите на първичната медицинска помощ и непосредствено свързаните с нея здравни грижи. Това постави началото на формиране на нова култура в предоставяните на населението здравни грижи, която, без да изключва тесния биомедицински подход за здравето и болестите, се простира извън неговите граници. Тук се има предвид нарастването на инициативите за промоция на здравето посредством влияние върху околната среда и начина на живот на общата популация.

Свързването на обществената ангажираност с личната отговорност на професионалистите по здравни грижи също има успех, тъй като промоцията на здравето и здравната просвета накараха немалко граждани да осъзнаят, че съвременния живот и околната среда носят рискове за здравето.

Паралелно с това се разработват и въвеждат нови нискоразходни технологии в подкрепа на здравните грижи от обсега на първичната извънболнична медицинска помощ: електрокардиография, биомедицинско оборудване за диагностика, медикаментозни и инструментални набори за неотложна медицинска намеса. Сега във всяка практика за първична извънболнична медицинска помощ активно се използват компютри.

Но за да посрещне успешно предстоящите предизвикателства, системата за ,,здравни грижи” в сектора „,nъpвична извънболнична медицинска помоще” трябва ускорено да развие своите силни страни и да започне да предлага здравни грижи, които трудно се предоставят от разпокъсаните, вертикално разположени изпълнители на медицинска помощ. А това може да се постигне чрез развиване на функциите, посочени Наредба на МЗ №1/08.02.2011год., които са свързани с предлагането на интегрирани услуги на и с помощта на пациентите и обществото. Без съмнение тази интеграционна роля трябва да има три взаимодопълващи се измерения: функционално, организационно и образователно.

Функиионалната интеграция предполага, че наред с епизодичните здравни грижи по повод на заболяване трябва да намери своето място и интегрираният подход към здравните потребности на индивида, семейството и обществото. Социално ориентираната пьрвична здравна грижа трябва да докаже, че може да спомогне за значително подобряване на здравето по един по-ефективен и ефикасен начин.

Организационната интеграция трябва да се съсредоточи върху начина, по който функционира системата на здравните грижи в индивидуалните и груповите практики за първична извънболнична медицинска помощ. Концепцията за групови практики трябва да се наложи по начин, който ще накара професионалистите по здравни грижи да обединят своите усилия в контекста на Алма-Атинската декларация, а не просто да работят под един покрив. И по-нататък, интегрирането на различни субекти в системата, която предоставя здравни грижи, предполага, че тя трябва ясно да определи границите на своите правомощия (в съответствие с Наредба на МЗ №1/08.02.2011 год.) и да работи в тясно сътрудничество със:

- лечебните заведения за специализирана извънболнична помощ;

- болниците;

- социалните услуги;

- органите и заведенията за обществено здравеопаз- ване, за да подобри качеството на грижите за пациентите.

Образователната интеграџия трябва да бъде ориентирана към усвояване на знания и умения, които не са застъпени по подходящ начин в настоящите програми на университетското и следдипломното обучение на професионалистите по здравни грижи. Ключовите инициативи в тази област трябва да бъдат насочени към подобряване на университетско обучение по проблемите на първичните извънболнични здравни грижи на всички участващи в екипите за тяхното изпълнение, както и на тяхната специализирана подготовка и непрекъсната квалификация.

\section{За ролевата значимост на сестринските грижи}

Медицинските сестри са най-многобройната група професионалисти в системата на здравеопазването, поради което значимостта им във функционирането на лечебните заведения не подлежи на съмнение. В сектора „Първична извънболнична медицинска помощ“" и в някои от по-малките населени места те са първата, най-постоянната и последната допирна точка на пациентите със здравната система. Ето защо техният принос получава все по-голямо признание и все по-голяма обществена подкрепа за заздравяване и понататъшно развитие на техните функции.

Настъпи време, което налага медицинските сестри да се разглеждат като ефективни в разходно отношение изпълнители на здравни услуги в системата за първична медицинска помощ и в областта на общественото здравеопазване.

В Таблица 1, заимствана от R. Saltman и J. Figueras (European Healthcare Reform. Analysis of Current Strategies. Copenhagen. WHO. Regional Office for Europe, 1997), е направен опит за по-детайлно формулиране на константата „сестрински грижи/дейности на общопрактикуващ лекар”. Таблица 1. Работата на медицинската сестра и общопрактикуващия лекар в системата за първичната медицинска помош

Работата на медицинската сестра и общопрактикуващия лекар в системата за първичната медицинска помощ се основава на умения и ценности, които включват:

- обстойно познаване на социалната среда на пациента;

- координираща функция;

- образователна функция - просвещава лицата, които предоставят грижи на свои близки в домашни условия;

- разработване и поддържане на програми за предоставяне на здравни грижи;

- експертни умения, упражнявани лично или посредством друго лице;

- грижи не само за болните, но и за тези, които понастоящем са в добро здравословно състояние;

- специална отговорност за „крехките” и уязвими лица и/или групи от населението.

Следователно развитието на функциите на медицинските сестри в системата за първична медицинска помощ трябва да се възприеме като част от по-широката тенденция към увеличаване на ефективността в предлагането на здравни услуги/грижи.

И въпреки позитивната, по всички направления на първичната извънболнична медицинска помощ, роля на медищинските сестри не можем да не отбележим съществуването на признаци за бавна промяна на техния социален статус и за подценяване на техните възможности за предоставяне на добри здравни, хуманистични и психосоциални грижи. Разбира се в последно време тази представа, макар и бавно, започна да се променя. Но проблемите, свързани с 
ниското заплащане, незадоволителните условия на труд и ниския социален статус на медицинските сестри, работещи в системата за първичната извьнболнична медицинска помощ, продължават да бъдат на дневен ред.

\section{Библиография}

1. Закон за съсловната организация на медицинските сестри, акушерките и асистираните медицински специалисти. Обн. ДВ/03.06.2005 г.

2. Наредба на МЗ №1/08.02.2011 г. За професионалните дейности, които медицинските сестри, акушерките, асоциираните специалисти и здрав- ните асистенти могат да извършват по назначение на лекар или самостоятелно.

3. Godinho J. Tipping the balance towards primary health care: a research project of the Commision of the European Communities // Eur. J. Public Health. 1999.

4. Marinker M. Tte End of General Practice. The 1994 Bayliss Lecture - Private Ptient Plan, 1994.

5. Mullan F. Community-oriented primary care: an agenda for the 80 's // N. Engl. J. Med.-1982.

6. The challenge for Nursing and Midwifery in the 21st. Century - the Heathrow Debate-Lond.: Department of Health, 1994.

$$
* *
$$

\title{
ПРИЛОЖИМОСТ НА СУПЕРВИЗИЯ В СЕСТРИНСТВОТО В БЫЛГАРИЯ
}

\author{
С. Тончева
}

\section{RELEVANCE OF SUPERVISION IN NURSING IN BULGARIA}

S. Toncheva

\begin{abstract}
Рез юме. В последните 15-20 години у нас бе обърнато голямо внимание на съдържателната и методичната част на академичната подготовка на медицинските сестри - да развиват знания и умения, които най-добре ще гарантират качествени грижи, съобразени със съвременните научни постижения за да отговорят на потребностите на индивида, семейството, общността. Възможностите за автономна практика на медицинските сестри насочва вниманието в световен мащаб към квалифицираните работещзи сестри, към по-нататъшното им професионално и личностно развитие, към въвличането им в дейности като супервайзори. Ние изследваме проблем, който все още търси своите практически измерения в съвременната сестринска практика и дава шанс той да бъде рано опознат, дискутиран и на първо време, може би, пилотно приложен у нас. Прилагане на супервизия в сестринството има иновативен характер, но отваря една нова врата за развитие и обогатяване на сестринската професия и нейната автономност - като размишления и като действия, приложими в България.
\end{abstract}

S $\mathbf{u} \mathbf{m} \mathbf{m}$ a ry. In the last 15-20 years, much attention has been paid to the content and methodical part of the academic training of nurses-to develop knowledge and skills, which will best ensure quality care, tailored to the contemporary scientific achievements to meet the needs of the individual, family and society. Globally, the opportunities for autonomous nursing practice focus attention to qualified, employed nurses, to their further professional and personal development and their involvement in activities as supervisors. We are exploring an issue, which is still seeking its practical dimensions in contemporary nursing practice, giving a chance to get to know and discuss it, and perhaps pilot it in our country. The implementation of supervision in nursing is innovative at its core, but opens up new horizons for the development and improvement of the nursing profession and its autonomy-as reflections and as actions that are applicable in Bulgaria.

\section{Основни нормативни документи, регламентиращи обучението и професионамната реамизация \\ на медицинската сестра у нас}

Законодателната рамка за обучението и дейността на медицинската сестра в България включва редица закони и наредби, които регламентират обучението и професионалната реализация на медицинските сестри. Без да бъдем изчерпателни в правния анализ, ще направим преглед на основните нормативни документи, които изясняват статута на професията у нас.

Съгласно чл. 8а от Наредбата за единните държавни изисквания за придобиване на висше образование по специалностите „Медицинска сестра“", „Акушерка“" и „Лекарски асистент“ [4], завършващите специалисти получават задълбочени познания по дисциплините, които са в основата на сестринските грижи, включително достатъчно високо ниво на познание за организма, психологическите функции и поведението на здравите и болните хора, както и за социалната среда на човека. Те получават познания за същността и етиката на професията и общите принципи, за- сягащи здравето и сестринските грижи, подходящ практически клиничен опит, умения за работа съвместно със здравния персонал и други медицински специалисти.

Раздел II от Наредба № 1 от 08.02.2011 г. за професионалните дейности, които медицинските сестри, акушерките, асоциираните медицински специалисти и здравните асистенти могат да извършват по назначение или самостоятелно [6] регламентира изчерпателно дейностите, които медицинската сестра може да извършва самостоятелно в областите на промоция на здравето, превенция $и$ профилактика на болестите, медицински и здравни грижи и дейности, ресоциализация, реадаптация и рехабилитация, извъриване на манипулаиии. Тези професионални дейности могат да се осъществяват от медицинската сестра както самостоятелно, така и по лекарско назначение. Наредбата регламентира и професионалните дейности, които медицинската сестра извьршва по лекарско назначение.

В чл. 81 и чл. 82 от Закона за здравето [1] са посочени основните принципи и правото на достьпна медицинска помощ за гражданите, както и обхвата на медицинските услуги, извън обхвата на задължителното здравно осигуряване. Чл. 96 от Закона за здравето дефинира палиативните медицински 